\title{
Does corporate social responsibility affect earnings management? Evid- ence from family firms
}

\author{
Eva López-González ${ }^{a}$, Jennifer Martínez-Ferrero ${ }^{\mathrm{b}}$, Emma García-Meca $^{\mathrm{c}}$
}

a) c) Accounting and Finance Department, Universidad Politécnica de Cartagena, Murcia, España

b) Accounting and Finance Department, Universidad de Salamanca, Salamanca, España

\section{${ }^{a}$ Corresponding author}

E-mail address: evalopezgonzalez@yahoo.es

\section{A R T I C L E I N F O}

\section{Article history:}

Received 16 Nov 2018

Accepted 7 Feb 2019

Available online 1 July 2019

\section{JEL classification:}

M41

M14

\section{Keywords}

Corporate social responsibility

Family firms

Earnings management

Códigos JEL:

M41
M14

Palabras clave:

Responsabilidad social corporativa

Empresa familiar

Manipulación de la información

\section{A B S T R A C T}

The purpose of this paper is to shed light on the effect of corporate social responsibility performance on earnings management. We also examine the moderating role of family ownership on the association between earnings management and socially responsible performance. Based on an international sample of 6,442 firm-year observations from 2006 to 2014, we use several panel-data regression models. We find that social and environmental performance is positively related with earnings management; firms with a greater socially responsible performance show a higher discretionary behavior by promoting actions that mask the real financial and economic performance of the firm. However, we find that this positive relation is lower - moderated - in family-owned firms, mainly because of the fact that family firms show a greater socially responsible behavior aimed to preserve their socioemotional endowments and are negatively associated with earnings management practices.

(C)2019 ASEPUC. Published by EDITUM - Universidad de Murcia. This is an open access article under the CC BY-NC-ND license (http://creativecommons.org/licenses/by-nc-nd/4.0/).

¿Afecta la responsabilidad social corporativa a la manipulación de la información? Evidencia en empresas familiares

R E S U M EN

El objetivo de este artículo es intentar aclarar el efecto de la responsabilidad social corporativa en la manipulación de información. También examinamos el efecto moderador de la familia en la relación entre manipulación de información y responsabilidad corporativa. Basados en una muestra internacional de 6,442 observaciones empresa-año durante los años 2006-2014, usamos análisis de validez y modelos de regresión para datos de panel. Hemos concluido que el desarrollo social y ambiental está positivamente relacionado con la manipulación de información; las empresas con una mayor actividad de responsabilidad social muestran un mayor comportamiento de manipulación a través de la promoción de acciones que enmascaran la realidad financiera y económica de la sociedad. Igualmente, encontramos que esta relación positiva es moderada a la baja en empresas familiares, principalmente porque las empresas familiares muestran una mayor responsabilidad social pues están centradas en conservar sus legados emocionales y así mismo están negativamente asociadas con prácticas relativas a la manipulación de información.

(C)2019 ASEPUC. Publicado por EDITUM - Universidad de Murcia. Este es un artículo Open Access bajo la licencia CC BY-NC-ND (http://creativecommons.org/licenses/by-nc-nd/4.0/). 


\section{Introduction}

Do socially responsible companies follow more earning management practices (EM)? Considering that not all organizations behave in the same way, does this balance vary according to family ownership? These are the research questions examined in this study, with the aim of reinforcing the understanding of the effect played by socially responsible commitment in EM practices - reporting accounting results that do not correspond to those actually achieved (Kim et al., 2012) - and with the aim of exploring the research gap about the moderating effect of family businesses.

Companies may adopt different strategies for achieving and maintaining their legitimacy (Suchman, 1995) and their image in markets and society. They may also release information with the aim of improving social and environmental performance (Lindblom, 2010), and they may also use corporate social responsibility (CSR) to influence the general public and stakeholders' perceptions regarding their behavior (Dowling and Pfeffer, 1975). A stream of prior literature suggests that companies may mask their EM practices by providing loads of CSR information (Salewski and Zülch, 2014). What's more, Martinez-Ferrero et al., (2015) argued that companies might use CSR information to ensure and enhance their legitimacy, in order to compensate for their poor quality of financial information. Investors are not only interested in financial information but also in social and environmental one (Anderson and Frankle, 1980; Dhaliwal et al., 2014); therefore, according to Gavana et al (2017) those companies which are involved in EM activities may be more predisposed to provide CSR information as an expectation for the investors and markets to receive a good image of the company and, in this way, minimize the risk of financial monitoring. Given the importance of EM potential damage (Chih et al., 2008), it is quite interesting to analyze the relationship between CSR performance and EM as an unethical strategy that masks the real financial and economic data of the firm.

In addition to addressing the possibility that CSR practices may mask EM practices, this study makes a contribution with its focus on family ownership as a possible control mechanism that underlies the relationship mentioned above ( $\mathrm{La}$ Porta et al., 1998). It has been suggested that the presence of family blockholders may constitute a mechanism that inhibits this type of EM practice (La Porta et al., 1998; Surroca and Tribó, 2008). But also and in general, previous literature agrees in supporting the greater CSR commitment of family firms (e.g. Berrone et al., 2012; Cruz et al., 2014); family firms show higher social and environmental performance by meeting stakeholder's demands and preserving their socioemotional endowments (Gómez-Mejía et al., 2007; Cruz et al., 2014).

Considerable research has been addressed on the moderating effect of family business in several aspects and whether they behave differently from firms not owned by a family group. Although family firms have many similarities with non-family owned firms (Sharma, 2004), they are characterized by other features that make them unique and, therefore, explains the attention paid to this type of organizations.

According to the existence of mixed results on the relationship between CSR and earning management (Hong and Andersen, 2011; Kim et al., 2011; Gargouri et al., 2010; Shen and Chih, 2005; Shleifer, 2004; Prior et al., 2008) and in particular, within the family firm framework where evidence is scarce (Nekhili et al., 2017; Martin et al., 2016; Achleitner et al., 2014; Pazzaglia et al., 2013; Fisher et al., 2001), our paper focuses on the following. First, this research analyzes the effect that CSR may have on EM; is socially responsible commitment really ethical? Second, we focus our analysis on the moderating role that family ownership may cause in the relationship between CSR and earning management practices; are family firms moderating the relationship between CSR and EM mainly because they tend to be more socially responsible and show lower EM?

These research questions are examined with an internal sample of analysis composed of 6,442 firm-year observations from 2006 to 2014. Methodologically, several panel-data regressions are proposed. The results show that more socially responsible firms are more proactive to make use of EM activities. In addition, the main evidence supports the moderating role played by family ownership. The results also show that family ownership is negatively associated with a greater EM commitment but also in terms of interaction with corporate socially responsible practices. This result suggests that family-owned firms are more conscious in terms of maintaining their wealth and image in the society by "making well", by means of responsible actions and a correct disclosure of their accountancy states. Overall, this paper confirms the moderating effect of family ownership on the positive relation between CSR and EM practices.

This research contributes to previous literature in a number of ways. First, we explore the relationship between CSR and EM in family business, as prevalent among listed companies around the world (Burkart et al., 2003). Over the last few years, previous studies have addressed the relationship of family firms with CSR and EM, separately. However, they have found mixed evidence and, sometimes, the results are not generalizable; a possible cause could be the lack of study of additional variables that clearly affect the relationship, like ownership concentration.

Second, this research sheds some light on the two streams previously established by several authors in the family business context: CSR performance and EM activities. However, we clearly contribute by providing additional evidence to the previous one (e.g.; Riahi-Belkaoui, 2004; Prior et al., 2008; Chih et al., 2008; Gargouri et al., 2010; Kim et al., 2011) about the link between CSR and EM by documenting how socially responsible firms are more predisposed to promote EM practices.

Third, this research also contributes to the family business literature in the following ways. Considerable research has been conducted on the question of how family-owned firms behave, and particularly whether they behave differently from non-family-owned firms. This research contributes to the literature by providing new insights into socially responsible behavior and, even more, into its association with earning managements.

Finally, our consideration of temporal dimension of the data obtained, we use a range of years from 2006 to 2014, instead of a single year analysis carried out by different authors in the past (Ali et al., 2007) or far back-in-time periods from the moment of analysis (Fan and Wong, 2002; Anderson and Reeb, 2004; Wang, 2006). Furthermore, this study adopts an international approach rather than a single-country or region approach (Cascino et al., 2010; Lin et al., 2017; Moore et al., 2017; Gaaya et al., 2017, Gavana et al., 2017). While previous studies about the topics of CSR, family firms and EM developed a cross-sectional analysis, this study adopts a panel data approach that allows multiple comparisons among countries and years. A subtler contribution is methodological. This research employs econometric models based on dependence techniques for panel data-concretely, different Tobit regressions-representing additional added value. 
The remainder of this paper is structured as follows. In Section 2, we describe the theoretical background that supports our research hypotheses. Section 3 describes the research model, data and sample. Finally, Sections 4 and 5 present the results obtained and the conclusions drawn, respectively.

\section{Theoretical framework and research hypotheses}

\section{Corporate social performance and earnings management}

CSR has been defined in several ways by different authors. For example, Carrol, in 1979, defined it as the responsibilities integrated in the company, taking into account the legal, ethic, economic and discretionary expectations that society has of organizations. In a more formal way, the World Business Council for Sustainable Development (2000) defines it as "the continuing commitment by business to behave ethically and contribute to economic development while improving the quality of life of the workforce and their families, as well as of the local community and society at large". In any case, CSR strategy is presented as an emerging alternative management model and considers the company as a set of relationships, not just between owners and managers, but also with parties or groups interested in the evolution of the company: employees, customers, suppliers, competitors, the environment, and society in general (Adams, 2002).

Moreover, previous studies (Orlitzky et al., 2003; Petersen and Vredenburg, 2009; El Ghoul et al., 2011; Mason and Simmons, 2013) agree in defending that one of the most important consequences of a proactive CSR strategy is increasing a firm's reputation. This reputation/image leads to positive reinforcement of the stakeholderst perception of and confidence in the firm (Deephouse and Carter, 2005; Fombrun et al., 2000; Young and Marais, 2011). In fact, in order to achieve this perception, financial transparency and accountability are becoming more crucial for CSR, being able to reduce the power that insiders have over outsiders, using their information advantage (Chih et al., 2008). In order to bear in mind for later analysis, firms communicate stakeholders the way they are responding to CSR activities by disclosing it, because it does affect their perceptions and they seem to believe that it is useful (Dierkes and Antal, 1985; Gray, Kouhy and Lavers, 1995).

On the other hand, given the importance that financial transparency and accountability have for CSR, we analyze several issues concerning EM. EM can be understood as those activities carried out in an intentional way by firm's managers to report accounting results that do not show an accurate image or situation of the company (Garcia-Osma et al., 2005). In this regard, two streams - opposite - coexist in the literature on the possible relationship between CSR and EM. What's more, authors like Chih et al., (2008) explained that the relationship between CSR and EM could be positive, negative or even no existing. On the one hand, firms have started to take care or pay attention to the adoption of different mechanisms of behavior, whose aim is to reconcile business with ethical or social goals. In this regard and in our matter of study, different authors (Hong and Andersen, 2011; Kim et al., 2011; Shen and Chih, 2005; Shleifer, 2004) have found a good relationship between socially responsible practices and the level of EM; these authors state that these practices are less common in companies with a great commitment to responsible practices, on accounting of their emphasis on providing a transparent image of the situation of the company and its management. Moreover, several studies have found that companies have accepted their social obligations and, there- fore, managers feel the need of doing what is right; to carry transparent and honest management activities (Phillips et al., 2003; Jones, 1995). This is the reason why, a smaller use of EM actions from managers that behave more ethically and transparent responsible could be expected. Therefore, CSR is used to win support and protection from stakeholders, trying to show the market their good behavior, providing an extensive disclosure of information (Gelb and Strawser, 2001). Thus, as Chih et al., (2008) argue, for high CSR firms, in order to maintain financial transparency, they should not engage in EM or, at lease, engage less, which could be translated into a negative relationship between these variables. However, while the support for the negative relationship between CSR and EM has recently gained value, there also exists a different point of view, stating that CSR practices may hide managers' behavior, because they try to hide the fact that they are focused on EM activities (Gargouri et al., 2010; Prior et al., 2008). In this line, studies have adopted, as their starting point, the traditional agency problem, where the separation of ownership and control is done, playing an important role for managers (agents) to make use of opportunistic actions, whose objectives might be different from those of shareholders (principals). In this context, it has been noted that CSR can exacerbate agency problems (Leuz et al., 2003) and motivate managers to use the information they posses to make decisions based on their own interests and against those of external groups.

In this vein, Chih et al., (2008) state that if socially responsible firms try to meet the demands of multiple stakeholders, they could damage their financial performance, and therefore, manage EM in order to upward the expected results. Meanwhile, Riahi-Belkaoui (2004) also found that these types of firms with high levels of CSR performance made use of more discretionary accruals.

Building our hypothesis under the above argument we analyze the effect that CSR has on EM and propose the following hypothesis:

H1: CSR performance positively affects EM.

\section{The moderating role of family firms}

Once the possible relationship between CSR and EM has been proposed, we continue examining this relationship within the family business sphere. We focus on family ownership as a possible control mechanism that underlies the relationship mentioned above (La Porta et al., 1998). It has been suggested that the presence of family blockholders may constitute a mechanism that inhibits discretionary behaviors (La Porta et al., 1998; Surroca and Tribó, 2008). Thus, family ownership could moderate the expected positive relationship between CSR and EM.

The research interest from the academia of focusing on family firms can corresponds, at least in part, to the fact that they are considered the greatest contributors to the world's economic activity (Duh et al., 2009; IFERA 2003). Following Miller and Le Breton-Miller (2003), family business can be defined as "one in which a family has enough ownership to determine the composition of the board, where the CEI and at least one other executive is a family member, and where the intent is to pass the firm to the next generation".

According to Chua et al., (1999) and Déniz and Cabrera (2005), the uniqueness of a family firm is the influence of a family or family group on ownership, management, governance and succession, and on the definition of the objectives and strategies. We suggest there are two strategies that 
are strongly influenced by the family: the use and final objective of CSR practices and the attitude towards managerial control of earnings, i.e. the possibility that managers have to use their discretionally in the decision-making process to satisfy their own interests.

Furthermore, in regard to the institutional theory, it can be said that one of the primary means that firms utilize to demonstrate their behavior to the society or relevant stakeholders, or even to affect their perception, is CSR. Therefore, as was previously suggested, CSR information disclosure might be used as a mechanism to manage the reputational risk and avoid doubts about unethical practices (Bebbington et al., 2008).

The motivations which could be under CSR information revealing (Campopiano and Massis, 2015) from an unethical conduct - EM included - (Martin et al., 2016; Achleitner et al., 2014; Pazzaglia et al., 2013; Stockmans et al., 2010) in family firms, have been effectively managed, according to the socio-emotional wealth (SEW) approach. In other words, the moderating effect of family ownership responds to this perspective.

Regarding this theory, the behavior of family firms is not only focused on financial or economic objectives, but it is also influenced by the family wish to preserve the socio-emotional wealth; this concept is translated into those aspects of the firm that meet the affective needs of the family itself (GomezMejia et al., 2007). For instance, the continuity of the family as owners of the company. According to Kepner (1983), talking about belonging and affect, the place where family members satisfy their needs is the family firm. What's more, according to Berrone et al., (2012), family firms are a way of perpetuating the dynasty, by inheriting the business, family values and the image of the company.

To the best of our knowledge, previous literature has not addressed the relationship between CSR and EM in the family firm sphere, although some studies suggest the difference CSR and EM practices between family and non-family companies for each of them separately.

Regarding EM, there is a stream which supports the idea that family managers and owners - as majority - may be motivated to use EM practices in order to maintain the owning family's wealth in detriment of the minority shareholders' wealth (Fan and Wong, 2002). It might manage EM downwards as a way of reducing taxation and/or dividends, keeping their self-finance and, so, the family control (Achleitner et al., 2014). On the other hand, they can also manage earnings upwards to reduce the capability of incrementing debt financing and to prevent lenders interfering with appointments of the members of the board or covenant restrictions, which might all put the influence and control of the family in a risky position (Prencipe et al., 2008; Stockmans et al., 2010). Nonetheless, a vast of prior literature agree on defending that, in general family firms appoint a family member as CEO or director, exerting more control over the board and thereby reducing the incentives to manipulate earnings in their own interests (Ali et al., 2007). It is logical to think that in family firms, any member will be in favor of avoiding unethical practices like EM because of the close relation of the owners with the firm. The lower level of EM practices allows them to protect the firm's reputation, and consequently the family's one, from the possible negative effects that these practices may lay on the firm's reputation (Pazzaglia et al., 2013). This argument was also found by Martin et al., (2016), who stated that family firms are more risk averse than non-family firms to be detected using EM; therefore, they are not likely to engage in EM practices that cause any detrimental effect of firm's value, performance, image and so on. Being caught like this can cause the loss of SEW and the damage of their image and, what's more it would get them to further economic implications for the family because their wealth is highly concentrated in the firm's asset. So, in this sense and with respect to the agency theory, for some authors (Khan et al., 2013; Landry et al., 2013) family ownership can be seen as an internal mechanism which restricts the use of managerial earnings by decreasing the classical agency conflict between managers and owners.

Regarding the promotion of CSR strategies in family firms, the inherent argument of the orientation of family firms to socially responsible behavior arises from the $\mathrm{SEW}^{1}$ model proposed by Wiseman and Gómez-Mejía (1998) and GómezMejía et al., (2007). These authors argue that decisions made within family businesses respond primarily to the preservation of social-emotional endowment, which becomes the reference point for management decisions particularly those related to social and environmental concessions. Although some studies defend the weaker orientation towards CSR practices among family firms or of the non-existence of such differences between family and non-family firms (Hirigoyen and Poulain-Rehm, 2014), the traditional view is that family firms are usually characterized by non-financial aims, such as identity, reputation, longevity, and the preservation of a positive image in the public domain (Anderson and Reeb, 2004; Berrone et al., 2012; Marques et al., 2014). As theoretically supported by SEW theory, they tend to be more responsive to social issues and stakeholders than non-family firms (Marques et al., 2014; Gómez-Mejía et al., 2014).

From the above, we base our premise on two issues: (i) the greater CSR commitment of family firms; and (ii) that family firms exhibit a lower level of $\mathrm{EM}^{2}$. Thus, we analyze the effect that CSR has on EM, in family business and propose the following hypothesis.

H2: Family ownership moderates the positive relationship between CSR performance and corporate tax avoidance.

\section{Method}

\section{Sample selection and data collection}

The data for this study are the result of a combination of information availability in two databases for a period of analysis from 2006 to 2014. First, archival data were collected from Thomson Reuters Eikon, a database that compiles company information on business classification, balance sheets, income and cash flow statements, stock data, global ratios, analyst estimates, corporate actions and events, officers and directors, corporate governance and ownership, activism, and other fields. In this study, we took into consideration information for all the firms from the global benchmark stock indices from America, Europe, the Middle East, Africa (EMEA) and Asia, comprising 3,594 companies from 31 stock indices, once duplicated companies were removed. Second, we combined the firms' social and environmental performance from the Ethical Investment Research Service (EIRIS) database, a database that compiles information for

${ }^{1}$ SEW can be defined as the set of values - image, reputation, survival, status and so on. It tries to perpetuate the firm's attachment, as well as the family succession and control that a family achieves from their ownership (Berrone et al., 2012; Gómez-Mejía et al., [2007; 2014]).

${ }^{2}$ Both premises will be analyzed through initial tests proposed further in the article. 
companies' social and environmental performance for more than 30,000 firms. After excluding observations with missing financial, economic, and CSR information, a final sample of 6,442 firm-year observations (956 firms) spanning nine years (2006-2014) was available to test the hypotheses. The sample was unbalanced, because not all companies were represented in all periods. The firms were engaged in activities in different sectors and were from 28 different countries (Australia, Belgium, Bermuda, Canada, China, Denmark, Finland, France, Germany, Hong Kong, Ireland, Italy, Japan, Luxembourg, Macau, Mexico, Netherlands, New Zealand, Norway, Papua New Guinea, Russia, Singapore, South Africa, Spain, Sweden, Switzerland, the United Kingdom, and the United States).

\section{Measures}

\section{Earnings Management}

According to the accounting literature on EM, the discretionary component of accrual adjustment should be used as a measure of management discretionality, and therefore of accounting manipulation. Accrual adjustments are defined as the difference between profit and cash flows from operations and in view of the inherent difficulty of manipulating cash flows, the use of accrual adjustments would be the most feasible means for managers to modify the accounting result. As postulated by Garcia-Osma et al., (2005), accruals are not all discretionary, hence the aim of separating the discretionary component from the non-discretionary one in order to determine the presence and extent of EM. This measure was first proposed by Healy (1985) and DeAngelo (1988), although the study by Jones (1991) represented a landmark in this line of research.

The model applied in the present analysis is a modification of that proposed by Jones. All models include dummy variables identifying the country of origin, because the sample size precludes estimating models by sector and country. This procedure was used previously by Prior et al., (2008).

Jones (1991) proposed that the components of accrual adjustments should be separated using a linear regression model. This model accounted for the total adjustment in terms of two variables: the change in sales and gross fixed assets. Subsequently, Defond and Jiambalvo (1994) corrected the main drawback of the standard Jones model, concerning its use of time series and the need for a large number of observations per firm, by proposing that the model should be obtained using annual cross-sectional data, grouping firms by sectors. Methodologically, following Jones (1991) and Dechow et al., (1995), total accrual adjustments (TAA) are defined as:

$\mathrm{TAA}_{\mathrm{it}}=\left[\left(\Delta \mathrm{CA}_{\mathrm{it}}\right)-\left(\Delta \mathrm{CASH}_{\mathrm{it}}\right)\right]-\left[\left(\Delta \mathrm{CL}_{\mathrm{it}}\right)-\left(\Delta \mathrm{RLTP}_{\mathrm{it}}\right)\right]-\mathrm{DA}_{\mathrm{it}}$ (1)

where $\Delta \mathrm{CA}_{\mathrm{it}}$ represents the change in current assets for firm i in period $\mathrm{t}, \Delta \mathrm{CASH}_{\mathrm{it}}$ reflects the change in cash held and short term financial investments for firm i in period t, $\Delta \mathrm{CL}_{\mathrm{it}}$ is the change in current liabilities for firm $i$ in period $t, \Delta$ RLTP $_{i t}$ is the change in reclassified long term obligations for firm $i$ in period $t$, and $\mathrm{DA}_{\mathrm{it}}$ is the depreciation and amortization for firm $i$ in period $t$.

On the basis of equation (1), accruals are calculated using an explanatory model. The difference between actual and expected accrual adjustments (taking into account growth, company assets and the accounting result) represents the discretionary or unexplained component of accrual adjustments and acts as a measure of management discretion in the reporting of results. The standard Jones model uses the following procedure to separate the discretionary from the nondiscretionary component:

$\frac{\mathrm{TAA}_{\mathrm{it}}}{A_{i, t-1}}=\propto_{1, t}\left(\frac{1}{A_{i, t-1}}\right)+\propto_{2, t}\left(\frac{\Delta \text { Sales }_{\mathrm{it}}}{A_{i, t-1}}\right)+\propto_{3, t}\left(\frac{\mathrm{PPE}_{\mathrm{it}}}{A_{i, t-1}}\right)+\varepsilon_{t}$

where $\mathrm{TAA}_{\mathrm{it}}$ are the total accrual adjustments for firm $\mathrm{i}$ in period $\mathrm{t} ; A_{i, t-1}$ represents the assets of firm i in period $\mathrm{t}-1$ and this is used as a deflator to correct possible problems of heteroskedasticity; $\Delta$ Sales $_{\text {it }}$ is the change in sales for firm $i$ in period t; $\mathrm{PPE}_{\mathrm{it}}$ represents the property, plant and equipment of firm $\mathrm{i}$ in period $\mathrm{t} ; \propto_{1, t}\left(\frac{1}{A_{i, t-1}}\right)+\propto_{2, t}\left(\frac{\Delta \text { Sales }_{\mathrm{it}}}{A_{i, t-1}}\right)+\propto_{3, t}$ $\left(\frac{\mathrm{PPE}_{\mathrm{it}}}{A_{i, t-1}}\right)$ are the non-discretionary accrual adjustments, and [image1.pdf] the discretionary accrual adjustments for firm i in the year t. Non-discretionary accrual adjustments (NDAA) are calculated by replacing the coefficients in equation (2) with the values obtained by Ordinary Least Squares. The discretionary accrual adjustments (DAA) are the residuals of this calculation.

In the modified Jones model (Dechow et al., 1995, equation 3), the TAA use the variation in sales less accounts receivable (used to measure the growth of the company, as its working capital is closely linked to sales), and less the item property, plant and equipment, which is used to measure the depreciation costs contained in the discretionary adjustments. It is assumed that not all sales are necessarily non-discretionary and that this will depend on the item to be received.

$\frac{\mathrm{TAA}_{\mathrm{it}}}{A_{i, t-1}}=\propto_{1, t}\left(\frac{1}{A_{i, t-1}}\right)+\propto_{2, t}\left(\frac{\Delta(\text { Sales }-A * R)_{\mathrm{it}}}{A_{i, t-1}}\right)+\propto_{3, t}\left(\frac{\mathrm{PPE}_{\mathrm{it}}}{A_{i, t-1}}\right)+\varepsilon_{t}$ (3)

where $A * R$ represents accounts receivable, and the other variables are as defined in equation 2 . Note that in this model, the coefficients are calculated using the original Jones model (1991) and that the modification is made only for the calculation of the non-discretionary adjustments. Again, the discretionary accrual adjustments (DAA) are the residuals of this calculation an as termed as "EM Dechow". The modified Jones model is the approach most often used in empirical studies of EM; see, for example, Warfield et al., (1995), Dechow et al., (1995), Peasnell et al., (2005) and Teoh et al., (1998), among many others.

In order to include robust analyses in the present study, we also calculate the DAA using other models, such as Kothari et al., (2005). Following Prior et al., (2008), Sun et al., (2010) and Kim et al., (2012), we use the Kothari et al., (2005) model to determine the performance effect within DAA, thus improving the Jones model modified by Dechow et al., (1995). The model proposed by Kothari et al., (2005) is characterized by the incorporation of a non-deflated constant and the return on assets, or financial profitability. All variables (except the constant) are deflated by the total assets for the previous period and are calculated by cross estimation. This model provides increased reliability and higher quality results, by resolving the question of whether differences in DAA may derive from differences in performance.

$$
\begin{aligned}
& \frac{\mathrm{TAA}_{\mathrm{it}}}{A_{i, t-1}}=\propto_{0, t}+\propto_{1, t}\left(\frac{1}{A_{i, t-1}}\right)+\propto_{2, t}\left(\frac{\Delta(\text { Sales }-A * R)_{\mathrm{it}}}{A_{i, t-1}}\right)+\propto_{3, t} \\
& \left(\frac{\mathrm{PPE}_{\mathrm{it}}}{A_{i, t-1}}\right)+\propto_{4, t}\left(\frac{\mathrm{ROA}_{\mathrm{it}}}{A_{i, t-1}}\right)+\varepsilon_{t}(4)
\end{aligned}
$$

The NDAA are calculated by replacing the coefficients in equation (5) with those obtained from equation (4), as in 
the original modified Jones model.

$\mathrm{NDAA}_{\mathrm{it}}=\hat{\propto}_{0, t}+\hat{\propto}_{1, t}\left(\frac{1}{A_{i, t-1}}\right)+\hat{\propto}_{2, t}\left(\frac{\Delta(\text { Sales }-A * R)_{\mathrm{it}}}{A_{i, t-1}}\right)+$ $\hat{\propto}_{3, t}\left(\frac{\mathrm{PPE}_{\mathrm{it}}}{A_{i, t-1}}\right)+\hat{\propto}_{4, t}\left(\frac{\mathrm{ROA}_{\mathrm{it}}}{A_{i, t-1}}\right) \varepsilon_{t}$

The DAA are then obtained by subtracting the NDAA from the TAA value obtained in equation (1), as shown in equation (6). The DAA represent the unexpected or abnormal accruals adjustments that constitute the variable taken as a measure of EM termed as "EM_Kothari".

$\mathrm{DAA}_{\mathrm{it}}=\mathrm{TAA}_{\mathrm{it}}-\mathrm{NDAA}_{\mathrm{it}}(6)$

\section{Corporate social responsibility performance}

CSR performance is measured using a multidimensional construct addressing all the activities carried out by the firms in question, especially with regard to social and environmental aspects (Carroll, 1979). In this case, information on CSR was compiled from the EIRIS database, which is widely used in academic research (see, among others, Fabrizi, Mallin and Michelon, 2013; Martínez-Ferrero, Banerjee and García-Sánchez, 2016). Through the information that companies disclose online and through questionnaires and surveys sent to companies, EIRIS addresses different areas, including environmental, human rights, employees, stakeholders, and board social issues, as shown in Table 1, assigning criteria grades to specific attributes addressing each of these areas. This procedure might involve a subjective assessment of relevant corporate practices, but the topics addressed and the questions posed are designed in such a way to enable a reasonable assessment of the activities evaluated. Moreover, EIRIS combines a broad range of environmental, board, and socio-labor data points to assess how companies respond to the various sustainability challenges they face and to identify corporate leadership in tackling environmental, board, and social challenges through policies, systems, reporting, and documented improvements in performance.

To obtain the level of CSR of companies, we make use of an aggregate measure that takes into consideration a range of important issues (environmental, human rights, stakeholders, employees, and governance) across companies, according to the 26 issues shown in Table 1. Similar to Fabrizi et al., (2013) and Martínez-Ferrero et al., (2016), we transform the EIRIS criteria rating for each measure into a numerical rating. According to the scoring criteria of EIRIS (inadequate, weak, moderate, good, and exceptional), we assign five values: 0 , $1,2,3$, and 4. Overall, companies are considered socially responsible with regard to a specific aspect, when the score is above the threshold of 2 , and are otherwise not considered sustainable. Because "CSR" is determined based on the nonweighted sum of these 26 items, it is in the range 0 to 104 .

\section{Family firms}

According to O'Boyle, Rutherford and Pollack (2010, p. 311), "family involvement represents a substantial family presence in ownership, governance, management, succession, and/or employment." Among these aspects, we focus on family ownership to verify the moderating role played by it in the relationship between CSR and tax avoidance. Although other studies use not only family ownership, but also other indicators of family control, such as the frequent involvement of family members in management (see, e.g., Block and Wagner, 2013; Dyer and Whetten, 2006; GomezMejía et al., 2007; Marques et al., 2014), these are strongly correlated with the percentage of equity ownership held by
Table 1

CSR indicator variable composition

\begin{tabular}{|c|c|c|c|c|c|}
\hline Human Rights Issues & Inadequate & e Weak & Moderate & Good & Exceptional \\
\hline $\begin{array}{l}\text { What is the extent of policy } \\
\text { addressing human rights issues? }\end{array}$ & 0 & 1 & 2 & 3 & 4 \\
\hline $\begin{array}{l}\text { What is the extent of systems } \\
\text { addressing human rights issues? }\end{array}$ & 0 & 1 & 2 & 3 & 4 \\
\hline $\begin{array}{l}\text { Does the Company report on human } \\
\text { rights issues? }\end{array}$ & 0 & 1 & 2 & 3 & 4 \\
\hline
\end{tabular}

rights issues?

Environmental Issues

How does EIRIS rate the Company's 0 environmental management system?

How does EIRIS rate the Company's 0 environmental policy system?

How does EIRIS rate the Company's 0 environmental reporting system?

What level of improvements in environmental impact can the Company demonstrate?

Stakeholders Issues

Does the Company have policies on 0

maintaining good relations with

customers and/or suppliers?

How clear is the evidence of systems 0 to maintain good relations with

customers and/or suppliers?

How many stakeholder issues have 0 been allocated to board members?

How clear is the Company's

commitment to community or

charitable work?

What level of engagement with

stakeholders is disclosed by the Company?

How good are the Company's policies 0 towards its stakeholders overall?

How good is the Company's quantitative reporting on stakeholder relationships?

How good are the Company's management systems for stakeholders overall?

\section{Employees Issues}

How good is the Company's policy on 0 equal opportunity and diversity issues?

How clear is the evidence of systems 0 and practices to support equal opportunities and diversity?

How clear is the evidence of health \& 0 safety systems?

How clear is the evidence of systems 0 to manage employee relations?

How clear is the evidence of systems 0 to support employee training and development?

How clear is the evidence of systems 0 and practices to advance job creation and security?

\section{Governance Issues}

Does the Company have a code of 0 ethics and, if so, how comprehensive is it?

Does the Company have a system for 0 implementing a code of ethics and, if so, how comprehensive is it?

What is the extent of the Company's 0 policy for countering bribery?

What is the extent of the Company's 0 system for countering bribery?

What is the extent of the Company's 0 reporting on countering bribery?

Values for CSR

0

$\begin{array}{llll}1 & 2 & 3 & 4 \\ 1 & 2 & 3 & 4 \\ 1 & 2 & 3 & 4 \\ 1 & 2 & 3 & 4\end{array}$


the family (Berrone et al., 2012).

Thus, family firm is most commonly measured by means of the percentage of voting rights held or of ownership and threshold values applied, including 5\% (Berrone et al., 2012; Chen et al., 2008), 10\% (Mok, Lam and Cheung, 1992), and even 25\% (Chau and Leung, 2006). Among the ample range of possibilities, in our study the explanatory variable of ownership concentration is taken as "Family", a dummy variable (Kashmiri and Mahajan, 2010; Landry et al., 2013) that takes the value 1 if the largest shareholder is a family member with more than $20 \%$ of the votes, and 0 otherwise in 2006 , the first year of the period analyzed ${ }^{3}$ (Cruz et al., 2014; MartínezFerrero et al., 2016; Rodríguez-Ariza et al., 2017). A dichotomous measure of family control has been used in numerous family business studies (Berrone et al., 2012; Steijvers et al., 2014). Also, the $20 \%$ cut-off should be interpreted in light of a long stream of research on control of large publicly traded firms that use an ownership threshold as low as 5\% to proxy a principal's capacity to exert major influence over the firm's affairs (e.g. Hambrick and Finkelstein, 1995).

\section{Control variables}

We also include a set of variables in the analyses to account for possible alternative explanations. These control variables were included in our regression models, according to previous studies (Prior et al., 2008; Surroca and Tribó, 2008; Chen et al., 2008; Kim et al., 2012; Laguir et al., 2015; Lin et al., 2017; Moore et al., 2017).

Regarding firm aspects, "Leverage" shows the firm leverage as the natural logarithm of the ratio of total debt to total equity; and "Loss" represents an indicator variable coded 1 if income before extraordinary items is less than zero and 0 otherwise. Based on previous studies, the relationships between debt ratio, loss indicators and EM are unclear. Firstly, we would expect to observe a positive relationship between them (as Park and Shin, 2004, supported); companies with higher level of debt or negative income, in order to avoid all possible losses that might arise from disclosure, have an incentive to manipulate or upraise their accounting results. Among others, Sweeney (1994) and Press and Weintrop (1990) agree on this positive relationship between EM and the level of indebtedness or loss. However, authors like Dechow and Skinner (2000) reported that the greater the debt, the lower the EM; Chung and Kallapur (2003), meanwhile, found no evidence of the relationship between these variables. "Size" represents firm size and was measured as the natural logarithm of total assets. It has been a failure from previous studies to establish a clear relationship between firm size and EM. On one hand, larger companies will have a greater incentive to adopt aggressive accounting policies, as their performance is critically scrutinized by the markets (Zhong et al., 2007). On the other hand, we would also expect to find a negative relationship, due to the fact that larger companies are subject to greater regulatory control, scrutiny by financial analysts and pressure from investors, normally, they have less incentive to carry out EM activities. All of these factors reduce the scope for discretionary action by company managers (Sánchez-Ballesta and García-Meca, 2007a). "Performance" represents firm performance by using Tobin's Q that is calculated based on the most usual proxy: the book value of total assets minus the book value of common equity plus the market value of common equity divided by the book value of total assets. Regarding performance, as said above, firms with financial problems, due to the fact that they do not wish to attract the attention of stakeholders, tend to lysis.
Figure 1

Research hypotheses

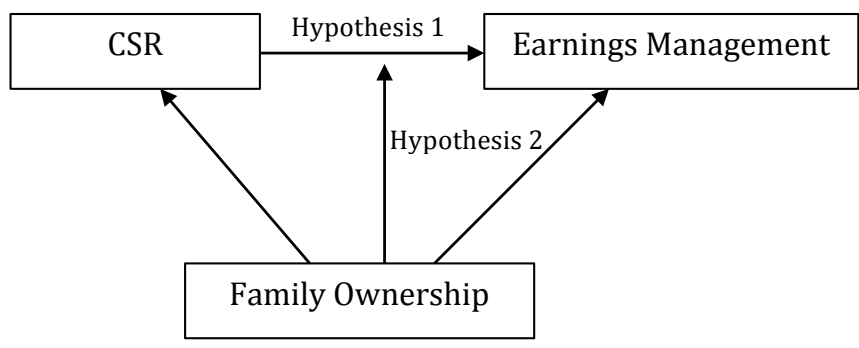

manipulate accounting results when they have to face with problems in their capital structure (Park and Shin, 2004). "R\&D intensity" represents the research and development investment effort as the ratio of research and development expenses to total assets. Regarding $R \& D$ intensity, several studies, as for Baber et al., (1991) and Dechow and Sloan (1991), have found that those companies that invest most in R\&D show greater incentives towards EM, in order to achieve the goals established or their targets.

Finally, 'Industry' ' is a dummy variable, where $j$ represents the different sectors of activity in which the companies in the sample operate;'Year ${ }_{n}$ 'is a dummy variable, where $n$ represents the years of the sample;'Country ${ }_{k}$ ' is a dummy variable, where $k$ represents the different countries in the sample.

\section{Method and technique of analysis}

This research examines how CSR performance could affect EM. Even more, we examine the moderating role played by family ownership. The above research questions are summarized in Figure 1.

For these aims, in Model Ia and Ib, EM through the different measures "EM_Dechow" and "EM_Kothari" is regressed on CSR indicator and control variables, respectively.

EM_Dechow/EM_Kothari ${ }_{\text {it }}=\beta_{1}$ CSR $_{\text {it }}+\beta_{2}$ Leverage $_{\text {it }}+$ $\beta_{3}$ Performance $_{\text {it }} \overline{+} \beta_{4}$ Size $_{i t}+\beta_{5}$ RD_Intensity ${ }_{i t}+\beta_{6}$ Loss $_{i t}+$ $\sum_{j=7}^{15} \beta_{j}$ Industry $_{i}+\sum_{n=16}^{23} \alpha_{n}$ Year $_{t}+\sum_{k=24}^{52} \alpha_{n}$ Country $_{i}+$ $\mu_{\mathrm{it}}+\eta_{i}$

\section{(Model IA and IB, respectively)}

Once we have regressed our basic models, we aim to examine the moderating effect of family ownership under the premise that family-owned firms exhibit a greater CSR commitment and performance and lower EM -these premises will be tested in initial analyses for ensuring them -. At this respect, for Model IIA and IIB respectively, we regressed our dependent variables of EM on CSR indicator variable, on our family business indicator and the interaction between both variables for examining the moderation effect.

EM_Dechow/EM_Kothari $=$ $\varphi_{1} \overline{\mathrm{CSR}}_{\mathrm{it}}+\varphi_{2}$ Family $_{\mathrm{it}}+\varphi_{3}$ CSR $*$ Family $_{\mathrm{it}}+\varphi_{4}$ Leverage $_{\mathrm{it}}+$ $\varphi_{5}$ Performance $_{i t}+\varphi_{6}$ Size $_{\text {it }}+\varphi_{7}$ RD_Intensity $_{\text {it }}+\varphi_{8}$ Loss $_{\text {it }}+$ $\sum_{j=9}^{17} \varphi_{j}$ Industry $_{i}+\sum_{n=18}^{25} \varphi_{n}$ Year $_{t}+\sum_{k=26}^{55} \varphi_{n}$ Country $_{i}+$ $\mu_{\text {it }}+\eta_{i}$

\section{(Model IIA and IIB, respectively)}

All the models incorporate a firm-specific effect, i, which controls the unobservable heterogeneity that affects firms' decision-making processes, while it represents the disturbance term. The firm is represented by $\mathbf{i}$, and $\mathbf{t}$ refers to the time period, $\beta$ and $\varphi$ are the parameters to be estim- 
ated. The econometric models used are based on dependence techniques for panel data that solves the disadvantages of cross-section and time-series; in particular, panel data enhances the consistency and explanatory power (Petersen, 2009). In addition, this technique allows us to control unobservable heterogeneity, which refers to the particular behavior and characteristics of each company included in the sample. Panel data methodology has additional advantages that enhance the possible econometric specifications as well as the parameter estimations - for example, more informative data, greater variability, less collinearity among variables, more degrees of freedom, and greater efficiency than cross-sectional or time-series methods (Martínez-Ferrero and García-Sánchez, 2017).

The dynamic panel estimator proposed by Arellano and Bond (1991), based on the generalized method of moments (GMM), is proposed as technique of analysis. More concretely, we use the two-step estimator of Arellano and Bond (1991). Suitable instruments adopted in GMM are the lagged values of the right-hand side variables included in the model as instruments, because they are uncorrelated with the error term when deriving the estimator (Arellano \& Bond, 1991).

\section{Empirical results}

\section{Descriptive results}

Table 2 shows the sample distribution by country and industry, focusing on the dichotomous between family and nonfamily firms. By country, there is a notably biased to US firms with around $42 \%$ of the total observations followed by those observations belong to Japan, United Kingdom, Canada and Australia. By industry, the greater representativeness corresponds to materials and capital goods. Moreover, Table 2 represents the distribution of the sample and of the family firms, by industry and country. The $6.77 \%$ (436 observations out of 6,442 ) of the companies were family business. Regarding their distribution, the countries with the highest percentages of family business were France, Germany, Spain and Hong Kong while the country with the lower presence, among the ones that had presence of family firms, was Japan. Regarding the industries, there is no presence of family firms in several industries but, among those which had, the highest presence lays on Automobiles and components (23.97\%) and the smallest presence on Materials (2.66\%).

Table 3 reports the mean, standard deviation, and bivariate correlation of the variables used in this research. Panel A reports the descriptive statistics. The mean values of "EM_Dechow" and "EM Kothari" are -0.002 and 0.001, respectively. But, the results change if we examine the family and non-family firms sub-sample. This result offers a first approximation of the lower use of EM activities in the environment of family firms in comparison with the non-family counterparts. The mean value of "CSR" is around 33, in a possible range $0-104$, meaning that despite the continuous growing in the last years, it still needs further investment CSR in general. Moreover, $6.8 \%$ of the firm-year observations belong to family firms. Regarding control variables, for example, firms show a mean size of around 23 (expressed in millions of Euros) on average. The correlation matrix shown in Panel B reports low or moderate correlation among variables. In no cases are high values obtained for the coefficients. Thus, multicollinearity among these variables is not a severe problem.
Table 2

Sample distribution by country and industry

\begin{tabular}{|c|c|c|c|c|c|c|}
\hline & & & \multicolumn{2}{|c|}{$\begin{array}{l}\text { Non family } \\
\text { firms }\end{array}$} & \multicolumn{2}{|c|}{ Family firms } \\
\hline & Freq. & Percent & Freq. & Percent & Freq. & Percent \\
\hline \multicolumn{7}{|l|}{ Panel A. Country } \\
\hline Australia & 497 & 7.71 & 497 & $100 \%$ & 0 & $0.00 \%$ \\
\hline Belgium & 9 & 0.14 & 9 & $100 \%$ & 0 & $0.00 \%$ \\
\hline Bermuda & 6 & 0.09 & 6 & $100 \%$ & 0 & $0.00 \%$ \\
\hline Canada & 502 & 7.79 & 424 & $84.46 \%$ & 78 & $15.54 \%$ \\
\hline China & 135 & 2.1 & 135 & $100 \%$ & 0 & $0.00 \%$ \\
\hline Denmark & 9 & 0.14 & 9 & $100 \%$ & 0 & $0.00 \%$ \\
\hline Finland & 9 & 0.14 & 9 & $100 \%$ & 0 & $0.00 \%$ \\
\hline France & 203 & 3.15 & 163 & $80.3 \%$ & 40 & $19.7 \%$ \\
\hline Germany & 181 & 2.81 & 147 & $81.22 \%$ & 34 & $18.78 \%$ \\
\hline Hong Kong & 181 & 2.81 & 149 & $82.32 \%$ & 32 & $17.68 \%$ \\
\hline Ireland; Republic of & 89 & 1.38 & 89 & $100 \%$ & 0 & $0.00 \%$ \\
\hline Italy & 9 & 0.14 & 9 & $100 \%$ & 0 & $0.00 \%$ \\
\hline Japan & 644 & 10 & 636 & $98.76 \%$ & 8 & $1.24 \%$ \\
\hline Jersey & 9 & 0.14 & 9 & $100 \%$ & 0 & $0.00 \%$ \\
\hline Luxembourg & 4 & 0.06 & 4 & $100 \%$ & 0 & $0.00 \%$ \\
\hline Macau & 5 & 0.08 & 5 & $100 \%$ & 0 & $0.00 \%$ \\
\hline Mexico & 6 & 0.09 & 6 & $100 \%$ & 0 & $0.00 \%$ \\
\hline Netherlands & 93 & 1.44 & 85 & $91.4 \%$ & 8 & $8.6 \%$ \\
\hline New Zealand & 30 & 0.47 & 30 & $100 \%$ & 0 & $0.00 \%$ \\
\hline Norway & 16 & 0.25 & 16 & $100 \%$ & 0 & $0.00 \%$ \\
\hline Papua New Guinea & 6 & 0.09 & 6 & $100 \%$ & 0 & $0.00 \%$ \\
\hline Russia & 28 & 0.43 & 28 & $100 \%$ & 0 & $0.00 \%$ \\
\hline Singapore & 145 & 2.25 & 142 & $97.93 \%$ & 3 & $2.07 \%$ \\
\hline South Africa & 31 & 0.48 & 31 & $100 \%$ & 0 & $0.00 \%$ \\
\hline Spain & 114 & 1.77 & 93 & $81.58 \%$ & 21 & $18.42 \%$ \\
\hline Sweden & 126 & 1.96 & 126 & $100 \%$ & 0 & $0.00 \%$ \\
\hline Switzerland & 113 & 1.75 & 105 & $92.92 \%$ & 8 & $7.08 \%$ \\
\hline United Kingdom & 523 & 8.12 & 491 & $93.88 \%$ & 32 & $6.12 \%$ \\
\hline United States of America & 2,719 & 42.21 & 2.551 & $93.82 \%$ & 168 & $6.18 \%$ \\
\hline
\end{tabular}

Panel B. Industry

Automobiles \& Components

Capital Goods

146

733

Commercial \& Professional Services 193

Consumer Durables \& Apparel

Consumer Services

Diversified Financials

Energy

Food \& Staples Retailing

Food, Beverage \& Tobacco

Health Care Equipment \& Services

Household \& Personal Products

Insurance

Materials

Media

Pharmaceuticals, Biotechnology \& Life S

Real Estate

Retailing

Semiconductors \& Semiconductor

Equipmen

Software \& Services

Technology Hardware \& Equipment

Telecommunication Services

Transportation

Utilities

$\mathrm{N}=6,442$ firm-year observations. 
Table 3

Descriptive statistics and bivariate correlations

\begin{tabular}{|c|c|c|c|c|c|c|}
\hline & \multicolumn{2}{|c|}{ Full Sample } & \multicolumn{2}{|c|}{ Non-family firms } & \multicolumn{2}{|c|}{ Family firms } \\
\hline & Mean & Std. Dev. & Mean & Std. Dev. & Mean & Std. Dev. \\
\hline EM_Dechow & -0.002 & 0.025 & -0.002 & 0.025 & -0.001 & 0.024 \\
\hline EM_Kothari & 0.001 & 0.025 & 0.000 & 0.025 & 0.002 & 0.024 \\
\hline CSR & 33.421 & 15.018 & 33.148 & 14.968 & 37.140 & 15.230 \\
\hline Family & 0.068 & 0.251 & & & & \\
\hline Leverage & 0.578 & 0.191 & 0.578 & 0.193 & 0.581 & 0.175 \\
\hline Performance & 0.668 & 0.146 & 0.668 & 0.149 & 0.670 & 0.106 \\
\hline Size & 22.952 & 1.242 & 22.921 & 1.246 & 23.383 & 1.098 \\
\hline R\&D_Intensity & 0.028 & 0.132 & 0.029 & 0.136 & 0.014 & 0.037 \\
\hline Loss & 0.922 & 0.268 & 0.920 & 0.271 & 0.945 & 0.228 \\
\hline
\end{tabular}

Panel B. Bivariate correlations

\begin{tabular}{|c|c|c|c|c|c|c|c|c|c|}
\hline & 1 & 2 & 3 & 4 & 5 & 6 & 7 & 8 & 9 \\
\hline 1. EM_Dechow & 1 & & & & & & & & \\
\hline 2. EM_Kothari & $0.994 * * *$ & 1 & & & & & & & \\
\hline 3. CSR & $0.042 * * *$ & $0.068 * * *$ & 1 & & & & & & \\
\hline 4. Family & 0.014 & 0.021 & $0.067 * *$ & 1 & & & & & \\
\hline 5. Leverage & $-0.091 * * *$ & $-0.069 * * *$ & $0.187 * *$ & 0.004 & 1 & & & & \\
\hline 6. Performance & $0.039 * *$ & 0.012 & - & 0.003 & $-0.632 * * *$ & 1 & & & \\
\hline 7. Size & $-0.100 * * *$ & $-0.062 * * *$ & $0.458 * *$ & $0.093 * * *$ & $0.269 * * *$ & $-0.199 * * *$ & 1 & & \\
\hline 8. R\&D_Intensity & $0.039 * *$ & $0.028 *$ & $-0.032 * *$ & $-0.029 * *$ & $-0.106 * * *$ & $0.045^{* * *}$ & $-0.064 * * *$ & 1 & \\
\hline 9. Loss & 0.017 & $0.028 *$ & $-0.24 *$ & $0.023 *$ & $-0.076 * * *$ & 0.002 & 0.006 & $-0.100 * * *$ & 1 \\
\hline
\end{tabular}

$\mathrm{N}=6,442$ firm-year observations.

Significance levels: ${ }^{*} \mathrm{p}<.10 .{ }^{* *} \mathrm{p}<.05 .{ }^{* * * \mathrm{p}}<.01$

$\mathrm{N}=6,442$ firm-year observations.

Significance levels: $* \mathrm{p}<.10 . * * \mathrm{p}<.05 . * * * \mathrm{p}<.01$

\section{CSR and EM: evidence on family-owned firms}

This research examines the following questions: does CSR affect EM?; how is this relationship in family-owned firms?. The possible moderating effect of family ownership in the relationship between CSR and EM is based on the premise that family firms exhibit a greater CSR commitment and lower EM. Before examining the relationship here proposed, we provide some initial test that allows us to support our two premise reported in Table 4 and ensure the validity of our future evidence.

On the one hand, this paper is based on the premise that family firms show a greater CSR commitment according to the SEW theory. In this respect, Model A regress CSR on family business indicator variable and the same control variables explained in method section ${ }^{4}$.

$\mathrm{CSR}_{\mathrm{it}}=\beta_{1}$ Family $_{\mathrm{it}}+\beta_{2}$ Leverage $_{\mathrm{it}}+\beta_{3}$ Performance $_{\mathrm{it}}+$ $\beta_{4}$ Size $_{i t}+\beta_{5} \mathrm{RD}_{-}$Intensity ${ }_{\mathrm{it}}+\beta_{6}$ Loss $_{\mathrm{it}}+$ $\sum_{j=7}^{15} \beta_{j}$ Industry $_{i}+\sum_{n=16}^{23} \alpha_{n}$ Year $_{t}+\sum_{k=24}^{52} \alpha_{n}$ Country $_{i}+$ $\mu_{\mathrm{it}}+\eta_{i}$ (Model A)

Results of Table 4 shows that the family firms indicator

\footnotetext{
${ }^{4}$ We present the results of the Tobit regression models for panel data used to test the hypotheses because of our dependent variable "CSR" is left and right censured (it takes values from 0 to 104).
}

has a positive and significant effect on "CSR" (coef. 2.652, $\mathrm{p}<0.01$ ). This result leads us to support our initial premise: family firms behave towards sociable responsibilities, with all its parties ${ }^{5}$. Family firms show a greater likelihood of promoting CSR practices, aiming to preserve their SEW and any reputational costs and to ensure the family firm survival and growth.

Moreover, the second premise of this paper is that family firms exhibit a lower EM, independently of the measure used. In this regard, Model B1 and B2 regress "EM_Dechow" and "EM_Kothari" on family firmst' indicator variable and the same control variables explained in method section, respectively, as follows:

EM_Dechow/EM_Kothari ${ }_{i t}=\beta_{1}$ Family $_{\text {it }}+\beta_{2}$ Leverage $_{i t}+$ $\beta_{3}$ Performance $_{\text {it }} \overline{+} \beta_{4}$ Size $_{\text {it }}+\beta_{5}$ RD_Intensity ${ }_{\text {it }}+\beta_{6}$ Loss $_{i t}+$ $\sum_{j=7}^{15} \beta_{j}$ Industry $_{i}+\sum_{n=16}^{23} \alpha_{n}$ Year $_{t}+\sum_{k=24}^{52} \alpha_{n}$ Country $_{i}+\mu_{\mathrm{it}}+$ $\eta_{i}$ (Model B1 and B2, respectively)

Results on Table 4 - by employing the GMM estimator of Arellano and Bond (1991) previously described - shows that family firms have a negative and significant effect on $\mathrm{EM}$ in the two different measures used in this study: coef. "EM_Dechow" -0.011, p $<0.01$ and coef. "EM_Kothari" -

\footnotetext{
${ }^{5}$ We would like to point out that our evidence is robust by alternative measure of family firms that consider the $50 \%$ of voting rights as threshold.
} 
Table 4

Impact of family firms on CSR and EM

\begin{tabular}{|c|c|c|c|c|c|c|}
\hline \multirow[t]{2}{*}{ Dependent Variable } & \multicolumn{2}{|c|}{$\begin{array}{c}\text { CSR } \\
\text { Model A }\end{array}$} & \multicolumn{2}{|c|}{$\begin{array}{c}\text { Earnings } \\
\text { Management } \\
\text { "EM_Dechow" } \\
\text { Model B1 }\end{array}$} & \multicolumn{2}{|c|}{$\begin{array}{c}\text { Earnings Management } \\
\text { "EM_Kothari" } \\
\text { Model B2 }\end{array}$} \\
\hline & Coef. & Std. Error & Coef. & Std. Err & ror Coef. & Std. Error \\
\hline \multicolumn{7}{|l|}{ Main effects } \\
\hline Family & $2.652^{* * *}$ & 0.637 & $-0.011^{* * *}$ & 0.003 & $-0.018^{* * *}$ & 0.003 \\
\hline \multicolumn{7}{|l|}{ Control variables } \\
\hline Leverage & 1.139 & 0.888 & $0.013 * * *$ & 0.003 & $0.013^{* * *}$ & 0.003 \\
\hline Performance & 0.850 & 1.351 & $0.011 * * *$ & 0.003 & 0.005 & 0.003 \\
\hline Size & $2.644^{* * *}$ & 0.209 & $-0.003^{* * *}$ & 0.000 & $-0.003^{* * *}$ & 0.000 \\
\hline R\&D_Intensity & 0.374 & 0.681 & $0.003^{* * *}$ & 0.001 & 0.000 & 0.001 \\
\hline Loss & $-0.448^{*}$ & 0.236 & $0.002 * * *$ & 0.001 & $0.002^{* * *}$ & 0.001 \\
\hline Industry dummies & Included & & Included & & Included & \\
\hline Year dummies & Included & & Included & & Included & \\
\hline Country dummies & Included & & Included & & Included & \\
\hline sigma_u & $13.179^{* * *}$ & * 0.321 & & & & \\
\hline sigma_e & $4.059 * * *$ & 0.039 & $\begin{array}{l}\text { AR(2) Are } \\
\text { Bond test }\end{array}$ & ellano- & $\begin{array}{l}\operatorname{Pr}>\mathrm{z}= \\
0.370\end{array}$ & $\begin{array}{l}\operatorname{Pr}>\mathrm{z}= \\
0.332\end{array}$ \\
\hline rho & 0.913 & 0.004 & Hansen te & & $\begin{array}{l}\text { Prob }>\text { chi2 }= \\
1.000\end{array}$ & $\begin{array}{l}\text { Prob }>\text { chi2 }= \\
1.000\end{array}$ \\
\hline
\end{tabular}

$0.018, \mathrm{p}<0.01$. These results support our second premise: firms with a higher family ownership exhibit a lower EM than non-family owner firms.

Estimated coefficients and associated standard errors are reported. The results are robust according to another alternative measure that considers $50 \%$ ownership.

In what follows, we present the results of our regressions models. Table 5 provides evidence of the effect of CSR on EM. The results of the GMM regression models used to test the relationships proposed were obtained using Stata software. For each explanatory variable of GMM regressions, we report the coefficient and the standard error associated with it.

Once the premises have been supported, we move forward to find answers to our hypotheses 1 and 2 . In this regard, Table 5 shows the results of the relationship between CSR and EM. Model IA shows that the "CSR" indicator has a positive and significant effect on "EM_Dechow" (coef. 0.001, $\mathrm{p}<0.01$ ); Model IB also reports a positive and significant effect of "CSR" towards "EM_Kothari" (coef. 0.001, p<0.01). The positive association between CSR and these indicators allows us to support hypotheses 1; that is, the higher the EM engagement the higher the use of CSR practices.

Supporting our hypothesis 1 about the greater level of EM actions in firms highly committed to CSR, in the following, we show the results of the examination of the possible moderating effect of family ownership in this relationship. Table 6 shows the relationship of CSR and EM with family firms, focusing on the interaction term between CSR and family ownership. Once again, "CSR" has a positive and significant effect on the "EM Dechow" and "EM Kothari" indicators (coef. 0.001, $\mathrm{p}<0.05$ and coef. $0.001, \mathrm{p}<0.01$, respectively). That is, the higher CSR performance, the higher level of EM practices. Accounting for the moderating role played by family ownership implies operating with coefficients. In Model IIA, the interaction "CSR_Family" shows a negative and significant effect on "EM Dechow" (coef. 0.001, p<0.01) and "EM_Kothari" (coef. -0.001, p<0.01), so the robustness measure is fulfilled. This means the following - accounting for Dechow et al., (1995)t's measure -: the positive impact of CSR on EM practices is lower in family
Table 5

Regression results on CSR and EM

\begin{tabular}{|c|c|c|c|c|}
\hline \multirow{2}{*}{$\begin{array}{l}\text { Dependent Variable } \\
\text { Variables }\end{array}$} & \multicolumn{2}{|c|}{$\begin{array}{c}\text { Earnings Managemen } \\
\text { "EM_Dechow" } \\
\text { Model IA }\end{array}$} & \multicolumn{2}{|c|}{$\begin{array}{c}\text { Earnings Management } \\
\text { "EM_Kothari" } \\
\text { Model IB }\end{array}$} \\
\hline & Coef. & Std. Error & Coef. & Std. Error \\
\hline \multicolumn{5}{|l|}{ Main effects } \\
\hline CSR & $0.001 * * *$ & 0.001 & $0.001 * * *$ & 0.001 \\
\hline \multicolumn{5}{|l|}{ Control variables } \\
\hline Leverage & -0.005 & 0.004 & $-0.007^{*}$ & 0.004 \\
\hline Performance & $-0.019 * * *$ & 0.006 & $-0.029 * * *$ & 0.006 \\
\hline Size & $-0.005^{* * *}$ & 0.001 & $-0.005^{* * *}$ & 0.001 \\
\hline R\&D_Intensity & 0.002 & 0.001 & $-0.002 *$ & 0.001 \\
\hline Loss & 0.001 & 0.002 & 0.002 & 0.001 \\
\hline Industry dummies & \multicolumn{2}{|l|}{ Included } & \multicolumn{2}{|l|}{ Included } \\
\hline Year dummies & \multicolumn{2}{|l|}{ Included } & \multicolumn{2}{|l|}{ Included } \\
\hline Country dummies & \multicolumn{2}{|l|}{ Included } & \multicolumn{2}{|l|}{ Included } \\
\hline $\begin{array}{l}\text { AR(2) Arellano-Bond test } \\
\text { Hansen test }\end{array}$ & \multicolumn{2}{|c|}{$\begin{array}{l}\operatorname{Pr}>z=0.373 \\
\operatorname{Prob}>\text { chi2 }=1.000\end{array}$} & \multicolumn{2}{|c|}{$\begin{array}{l}\operatorname{Pr}>z=0.337 \\
\text { Prob }>\text { chi } 2=1.000\end{array}$} \\
\hline
\end{tabular}

$\mathrm{N}=6,442$ firm-year observations. Significance levels: $* \mathrm{p}<.10 .{ }^{* * \mathrm{p}<.05} . * * * \mathrm{p}<.01$. Estimated coefficients and associated standard errors are reported.

firms (coef. $0.001+$ coef. $-0.001=0.000$ ) than in non-family firms (coef. 0.001).

Overall, the above results allow us to empirically support our hypothesis 2 about the moderating effect of family ownership on the relationship between CSR and EM. This moderating effect responds to the lower EM and greater CSR performance in family firms. First, the agency problem is supposed to be reduced when we are in a family firm context because of the fact that the agent and principal are the same. Second, we presume and evidence the higher CSR commitment of family firms in order to satisfy the stakeholder's needs related to social and environmental concessions and thus, preserving their socio-emotional endowments.

\section{Discussion of results}

Our initial evidence suggests that more socially responsible firms are those more oriented to report financial and economic data that do not correspond to those really achieved and using CSR as discretionary tool. As Gargouri et al., (2010), Prior et al., (2008) and Chih et al., (2008), we support the positive relationship between CSR and the level of EM. As these authors, we document how managers try to mask EM practices by CSR performance and thus, avoiding that shareholders and stakeholders identify and detect these discretionary actions which could lead to disciplinary actions by outside investors. As Chih et al., (2008), the positive link between CSR and EM is in accordance with their multiple objectives hypothesis; that is, socially responsible firms try to meet the demands of multiple stakeholders, because they could damage their financial performance, and therefore, manage EM in order to upward the expected results.

We also document the moderating effect of family ownership on the positive relationship between CSR and EM. In line with Chua et al., (1999) and Déniz ad Cabrera (2005), we provide evidence that confirms the influence of a family or family group on the definition of the objectives and strategies (like CSR and EM). 
Table 6

Regression results on CSR and EM and the Moderating Effect of Family Ownership

\begin{tabular}{|c|c|c|c|c|}
\hline \multirow{2}{*}{$\begin{array}{l}\text { Dependent Variable } \\
\text { Variables }\end{array}$} & \multicolumn{2}{|c|}{$\begin{array}{c}\text { Earnings Management } \\
\text { "EM_Dechow" } \\
\text { Model IIA }\end{array}$} & \multicolumn{2}{|c|}{$\begin{array}{c}\text { Earnings Management } \\
\text { "EM_Kothari" } \\
\text { Model IB } \\
\end{array}$} \\
\hline & Coef. & Std. Error & Coef. & Std. Error \\
\hline \multicolumn{5}{|l|}{ Main effects } \\
\hline CSR & $0.001 * *$ & 0.000 & $0.001^{* * *}$ & 0.001 \\
\hline Family & $-0.010 * * *$ & 0.002 & $-0.010 * * *$ & 0.002 \\
\hline CSR_Family & $-0.001 * * *$ & 0.000 & $-0.001 * * *$ & 0.001 \\
\hline \multicolumn{5}{|l|}{ Control variables } \\
\hline Leverage & -0.004 & 0.004 & -0.006 & 0.004 \\
\hline Performance & $-0.019 * * *$ & 0.006 & $-0.024 * * *$ & 0.006 \\
\hline SIZE & $-0.005^{* * *}$ & 0.001 & $-0.005 * * *$ & 0.001 \\
\hline R\&D_Intensity & 0.002 & 0.001 & $-0.002 *$ & 0.001 \\
\hline $\begin{array}{l}\text { Loss } \\
\text { Industry dummies }\end{array}$ & $\begin{array}{l}0.001 \\
\text { Included }\end{array}$ & 0.002 & $\begin{array}{l}0.002 \\
\text { Included }\end{array}$ & 0.002 \\
\hline Year dummies & Included & & Included & \\
\hline Country dummies & Included & & Included & \\
\hline $\begin{array}{l}\text { AR(2) Arellano-Bond test } \\
\text { Hansen test }\end{array}$ & $\begin{array}{l}\operatorname{Pr}>z=0 \\
\text { Prob }>\text { chi }\end{array}$ & $\begin{array}{l}375 \\
=1.000\end{array}$ & $\begin{array}{l}\text { Pr }>z=0 \\
\text { Prob }>\text { chi }\end{array}$ & $\begin{array}{l}338 \\
=1.000\end{array}$ \\
\hline
\end{tabular}

$\mathrm{N}=6,442$ firm-year observations. Significance levels: ${ }^{*} \mathrm{p}<.10 .{ }^{* *} \mathrm{p}<.05 .{ }^{* * *} \mathrm{p}<.01$. Estimated coefficients and associated standard errors are reported.

The results of the initial tests also allow us to support previous studies around how family firms show lower EM strategies. Overall, our findings contribute by advancing in the understanding of the effect of family ownership on EM actions, where there are two opposing streams. In this respect, we support the alignment effect proposed by Wang (2006), according to which a greater managerial ownership reduces the conflict of interests between owners and managers. In line with Ali et al., (2007) and Martin et al., (2016), family firms exhibit a lower classical agency problem between managers and owners, showing a lower orientation to the adoption of EM practices. Our evidence allows us to support how family firms avoid any unethical practices like EM that damage their reputation, image, and so on, and thus, their socio-emotional endowments. In line with agency theory and previous studies (like Khan et al., 2013 and Landry et al., 2013), family ownership restricts the use of managerial earnings by decreasing the classical agency conflict between managers and owners.

In this respect, we find that firms that engage in EM practices are those more proactive to invest in CSR activities with the aim of avoiding the negative effect that those unethical practices may give to the company. So, although the support for the negative relationship between CSR and EM has recently gained value, with these results, we found ourselves in the stream that Gargouri et al., (2010) and Prior et al., (2008) proposed; these authors stated that CSR practices may hide managers' use of EM activities. This stream has adopted the traditional agency problem, where the separation of ownership and control is done. In this context, CSR can exacerbate agency problems and motivate managers to use the information to make decisions based on their own interests and against of those of external groups, using EM practices (Chih et al., 2008) and, thus, exposing all the parties of the company to the risk of legal or other disciplinary actions by outside investors (Leuz et al., 2003). Moreover, regarding the moderating effect, our results show that family ownership decreases the risk of discretionary actions being used (Fields et al., 2001; Wang, 2006; Ali et al., 2007; Landry et al., 2013).

In addition, our supported premises also confirm and advance the understanding of the greater social and environmental commitment of family firms. We confirm how family firms are more incentive to invest in CSR strategies for responding to the preservation of their SEW (in line with evidence reported by Wiseman and Gómez-Mejía (1998), GómezMejía et al., [2007; 2014], Marques et al., [2014] and Cruz et al., [2014], among others). We clearly shed light on the positive association between family ownership and social and environmental performance.

\section{Conclusions}

The purpose of this paper is to shed light on the effect of CSR performance on firm EM and examine the moderating role played by family ownership. We have used an international sample composed of 956 international firms from 28 countries during the period 2006 to 2014.

We evidence that social and environmental performance is positively related with EM; firms with a greater socially responsible performance show a higher discretionary behavior by promoting actions that mask the real financial and economic performance of the firm. However, we find that this positive relation is lower - moderate - in family-owned firms, mainly because of the fact that family firms show a greater socially responsible behavior aimed to preserve their socio-emotional endowments and are negatively associated with EM practices. This result suggests that family-owned firms are more conscious in terms of maintaining their wealth and image in the society by "making well", by means of responsible actions and a correct disclosure of their accountancy states. Overall, this paper confirms the moderating effect of family ownership on the positive relation between CSR and EM practices.

Regarding practical implications, this study shows a more precise process for understanding the CSR performance accounting for managerial accruals and, at the same time, taking into account the moderating effect of family ownership. Thus, our research has practitioner merit as it helps, among others that might be interested, firms, managers, shareholders, investors, and stakeholders in analyzing how EM impacts on CSR as well as to realize the possible moderation that family ownership might have in this behavior. For companies, knowing how EM impacts on CSR is fundamental for determining CSR strengths and concerns. Firms and managers must be aware that they also take into consideration the needs of wider variety of stakeholders in their business decisionmaking. We provide information about how this decisionmaking and the promotion of CSR or EM activities vary according to family ownership. But, also, that family managers and directors favor the promotion of CSR performance goals as well as they must be aware about the negative impacts that EM activities may cause on their image and reputation. For investors - family and non-family members -, our results provide useful implications about the way that EM activities are carried out, in regard to CSR ones, being reduced or eliminated when the family presence is higher in order to preserve and reinforce their socioemotional endowments and image. Moreover, these results serve as guidelines or tools to investors and shareholders to design and configure 
compelling management teams and boards that favor CSR strategies and the avoidance of managerial accruals. They must be aware that family directors and managers can be effective and can provide additional benefits in the company. Thus, our framework sets guidelines and serves as a tool to configure right mechanisms together. Finally, for stakeholders, our evidence provides useful findings for understanding the benefits associated to family ownership and management in terms of CSR and managerial accruals, so as it softens the use of these last ones within the firm. From our results, stakeholders can understand the way that family firms influence a company management towards CSR and, therefore, meet their social and environmental demands as well as reduce the possible activities focused on EM.

Finally, these results should be interpreted carefully, because this research is subject to certain limitations. They should be considered before drawing conclusions from the results. First, regarding our CSR measure, it is measured as the unweighted sum of different environmental and social performance indicators, which are based on numerical scales. Although we believe this measure to be reliable and accurate, following previous studies (e.g., Fabrizi et al., 2013; Martínez-Ferrero et al., 2016), we are cautious about the possible bias it may include. It may not capture the true underlying practices. Future research could try to overcome this limitation with additional environmental and socially independent studies. Second, in this study, the variable that represents family businesses is a dummy in which the companies in the sample are classified as family, or non-family-owned firms, applying a 20\% cut-off point for ownership. Because of the lack of available information, it was not possible to perform a sensitivity analysis by considering alternative family firms, considering other aspects, such as succession. Thus, it could be interesting for future studies to verify these findings using other definitions of family businesses. Deriving from the previous limitation, we are not able to confirm the existence of a threshold at which point our results could be modified or could operate in a different way. For this reason, it would also be interesting for further research to analyze if a percentage of family ownership exists or, a level of family involvement that may shape the results obtained in the present study. Finally, future research could also examined industry and country-level factors that can affect the relationships here examined because of the impossibility of this paper to regress models of analysis by industry and country.

\section{Conflict of interests}

The authors declare no conflict of interests.

\section{References}

Adams, C. A. (2002). Internal organisational factors influencing corporate social and ethical reporting: Beyond current theorising. Accounting, Auditing \& Accountability Journal, 15(2), 223-250.

Anderson, J. C., \& Frankle, A. W. (1980). Voluntary social reporting: An iso-beta portfolio. Accounting Review, 55, 467479.

Anderson, R., \& Reeb, D. (2004). Board composition: balancing family influence in S\&P 500 firms. Administrative Science Quarterly, 49 (2), 209-237.

Ali, A., Chen, T. Y., \& Radhakrishnan, S. (2007). Corporate disclosures by family firms. Journal of Accounting and
Economics, 44 (1-2), 238-286.

Archleitner, A. K., Günther, N., Kaserer, C., \& Siciliano, G. (2014). Real earnings management and accrual-based earnings management in family firms. European Accounting Review, 23, 431-461

Baber, W.R., Fairfield, P.M., \& Haggard, J.A. (1991). The effect of concern about reported income on discretionary spending decisions: the case of research and development. Accounting Review, 66, 818-829.

Bebbington, J., Larrinaga, C., \& Moneva, J. M. (2008). Corporate social reporting and reputation risk management. Accounting, Auditing and Accountability Journal, 21 (3), 337-361.

Berrone, P., Cruz, C., \& Gómez-Mejía, L. R. (2012). Socioemotional wealth in family firms: theoretical dimensions, assessment approaches, and agenda for future research. Family Business Review, 25 (4), 258-279.

Burkart, M., Panunzi, F., \& Shleifer, A. (2003). Family Firms. Journal of Finance, 58(5), 2167-2201.

Campopiano, G., \& De Massis, A. (2015). Corporate social responsibility reporting: A content analysis in family and non-family firms. Journal of Business Ethics, 129(3), 511534.

Carrol, A.B. (1979). A three-dimensional conceptual model of corporate performance. The Academy of Management Review, 4 (4), 497-505.

Cascino, S., Pugliese, A., Mussolino, D., \& Sansone, C. (2010). The influence of family ownership on the quality of accounting information. Family Business Review, 23 (3), 246-265.

Chen, C., Lin, C., \& Lin, Y. (2008). Audit partner tenure, audit firm tenure, and discretionary accruals: Does long auditor tenure impair earnings quality? Contemporary Accounting Research, 25 (2), 447-471.

Chen, K. Y., Elder, R. J., \& Hsieh, Y. M. (2007). Corporate governance and earning management: The implications of corporate governance best-practice principles for Taiwanese listed companies. Journal of Contemporary Accounting and Economics, 3(2), 73-105.

Chen, S., Chen, X., \& Cheng, Q. (2008). Do family firms provide more or less voluntary disclosure? Journal of Accounting Research, 46(3), 499-536.

Chih, H. L., Shen, C. H., \& Kang, F. C. (2008). Corporate Social Responsibility, Investor Protection, and Earning Management: some international evidence. Journal of Business Ethics, 79, 179-198.

Chua, J.H., Chrisman, J. J., \& Sharma, P. (1999). Defining the family business by behavior. Entrepreneurship Theory and Practice, 23(4), 19-40.

Chung, H., \& Kallapur, S. (2003). Client importance, Nonaudit services and Abnormal accruals. Accounting Review, 78 (4), 931-955.

Cohen, D. A., \& Zarowin, P. (2010). Accrual-based and real earnings management activities around seasoned equity offerings. Journal of Accounting and Economics, 50 (1), 219.

Cruz, C., Larraza-Kintana, M., Garcés-Galdeano, L., \& Berrone, P. (2014). Are family firms really more socially responsible? Entrepreneurship Theory and Practice, 38 (6), 12951316.

Davidson, W. N., Xie, B., \& Xu, W. (2004). Market reaction to voluntary announcements of audit committee appointments: The effect of financial expertise. Journal of Accounting and Public Policy, 23 (4), 279-293.

DeAngelo, L. E. (1988). Managerial competition, information costs, and corporate governance. The use of accounting 
performance measures in proxy contests. Journal of Accounting and Economics, 10(1), 3-36.

Dechow, P.M., \& Skinner, D.J. (2000). Earnings management: reconciling the views of accounting academics,practitioners and regulators. Accounting Horizons, 14, 235-250.

Dechow, P. M., Kothari, S., \& Watts, R. (1998). The relation between earnings and cash flows. Journal of Accounting and Economics, 25 (2), 133-168.

Dechow, P.M., \& Sloan, R. (1991). Executive incentives and the horizon problem: an empirical investigation. Journal of Accounting and Economics, 14, 51-89.

Dechow, P. M., Sloan, R. G., \& Sweeney, A. P. (1995). Detecting earnings management. Accounting Review, 70(2), 193-225.

Deephouse, D.L., \& Carter, S.M. (2005). An examination of differences between organizational legitimacy and organizational reputation. Journal of Management Studies, 42(2), 22-2380.

DeFond, M. L., \& Jiambalvo, J. (1994). Debt covenant violation and manipulation of accruals. Journal of Accounting and Economics, 17(1-2), 145-176.

Déniz, M. C., \& Cabrera, M. K. (2005). Corporate social responsibility and family business in Spain. Journal of Business Ethics, 56 (1), 27-41.

Dhaliwal, D., Li, O. Z., Tsang, A., \& Yang, Y. G. (2014). Corporate social responsibility disclosure and the cost of equity capital: The roles of stakeholder orientation and financial transparency. Journal of Accounting Public Policy, 33, 328355.

Dierkes, M., \& Antal, A. B. (1985). The usefulness and use of social reporting information. Accounting, Organizations and Society, 10 (1), 29-34.

Dowling, J., \& Pfeffer, J. (1975). Organizational legitimacy: Social values and organizational behavior. Pacific Sociological Review, 18, 122-136.

Duh, M., Tominc, P., \& Rebernik, M. (2009). The importance of Family Enterprises in Transition Economies: Is It Overestimated? Eastern European Economics, 47 (6), 22-42.

El Ghoul, S., Guedhami, O., Kwok, C.C.Y., \& Mishra, D.R. (2011). Does corporate social responsibility affect the cost of capital? Journal of Banking and Finance, 35 (9), 2388-2406.

Fan, J. P., \& Wong, T. J. (2002). Corporate ownership structure adds the informativeness of accounting earrings in East Asia. Journal of Accounting Economics, 33, 401-425.

Fields, T. D., Lys, T. Z., \& Vincent, L. (2001). Empirical research on accounting choice. Journal of Accounting and Economics, 31 (1), 255-307.

Fisher, J., Gunz, S., \& McCutcheon, J. (2001). Private / public interest and the enforcement of a code of professional conduct. Journal of Business Ethics, 31 (3), 191-207.

Fombrun, C.J., Gardberg, N.A., \& Sever, J.M. (2000). The Reputation Quotient SM: A multi-stakeholder measure of corporate reputation. Journal of Brand Management, 7(4), 241255.

Gaaya, S., Lakhal, N., \& Lakhal, F. (2017). Does family ownership reduce corporate tax avoidance? The moderation effect of audit quality. Managerial Auditing Journal, 32 (7), 731-744.

Gargouri, R. M., Shabou, R., \& Francoeur, C. (2010). The relationship between corporate social performance and earning management. Canadian Journal of Administrative Sciences / Revue Canadienne Des Sciences De l'Administration, 27 (4), 320-334.

García-Osma, B. (2008). Board independence and real earnings management: the case of R\&D expenditure. Corporate Governance: An International Review, 16 (2), 116-131.

García-Osma, B., Gil de Albornoz-Noguer, B., \& GisbertClemente, A. (2005). La investigación sobre "earning management". Revista Española de Financiación y Contabilidad, 34 (127), 1001-1034.

Gavana, G., Gottardo, P., \& Moisello, A. M. (2017). Earning Management and CSR Disclosure. Family vs. Non-Family Firms. Sustainability, 9(12), 2327. https://doi.org/10. 3390/su9122327

Gelb, D. S., \& Strawser, J. A. (2001). Corporate social responsibility and financial disclosures: An alternative explanation for increased disclosure. Journal of Business Ethics, 33 (1), 1-13.

Gómez-Mejía, L. R., Haynes, K. T., Núñez-Nickel, M., Jacobson, K. J. L., \& Moyano-Fuentes, J. (2007). Socioemotional wealth and business risks in family-controlled firms: Evidence from Spanish olive oil mills. Administrative Science Quarterly, 52 (1), 106-137.

Gómez-Mejía, L.R., Cruz, C., \& Imperatore, C. (2014). Financial Reporting and the Protection of Socioemotional Wealth in Family-Controlled Firms. European Accounting Review, 23 (3), 387-402.

Gray, R., Kouhy, R., \& Lavers, S. (1995). Corporate social and environmental reporting. A review of the literature and a longitudinal study of UK disclosure. Accounting, Auditing and Accountability Journal, 8(2), 47-77.

Healy, P. M. (1985). The effect of bonus schemes on accounting decisions. Journal of Accounting and Economics, 7(1-3), 85-107.

Healy, P. M., \& Wahlen, J. (1999). A review of the earning management literature and its implications for standard setting. Paper prepared for discussion at the 1998 AAA/FASB Financial Reposting Issues Conference, Accounting Horizons, 13, 365-383.

Hirigoyen, G., \& Poulain-Rehm, T. (2014). The Corporate Social Responsibility of Family Businesses: An International Approach. International Journal of Financial Studies, 2, 240265.

Hong, Y., \& Andersen, M. L. (2011). The relationship between corporate social responsibility and earning management: an exploratory study. Journal of Business Ethics, 104 (4), 461-471.

Ifera (2003). Family business dominate. Family Business Review, 16 (4), 235-239.

Jones, J. J. (1991). Earnings management during import relief investigations. Journal of Accounting Research, 29(2), 193-228.

Jones, T. M. (1995). Instrumental stakeholder theory: A synthesis of ethics and economics. Academy of Management Review, 20(2), 404-437.

Kepner, E. (1983). The family and the Firm: A convolutional perspective. Family Business Review, 4(4), 445-461.

Khan, I., Chad, P. V., \& Patel, A. (2013). The impact of ownership structure on voluntary corporate disclosure in annual reports: evidence from Fiji. Accounting and Taxation, 5 (1), 47-58.

Kim, B., \& Yi, C. H. (2006). Ownership structure, business group affiliation, listing status, and earning management: Evidence from Korea. Contemporary Accounting Research, 23 (2), 427-464.

Kim, B., Li, Y., \& Zhang, L. (2011). Corporate Tax Avoidance and stock price crash risk: firm-level analysis. Journal of Financial Economics, 100 (3), 639-662.

Kim, Y., Park, M.S., \& Wier, B. (2012). Is earnings quality associated with corporate social responsibility? Accounting 
Review, 87 (3), 761-796.

Kinney Jr, W. R., Palmrose, Z., \& Scholz, A. (2004). Auditor independence, non-audit services, and restatements: was the U.S. government right?. Journal of Accounting Research, 42(3), 561-588.

Kothari, S., Leone, A. J., \& Wasley, C. E. (2005). Performance matched discretionary accrual measures. Journal of Accounting and Economics, 39(1), 163-197.

Martin, G., Campbell, J. T., \& Gomez-Mejia, L. (2016). Family control, socioemotional wealth and earning management in publicly traded firms. Journal of Business Ethics, 133 (3), 453-469.

Martinez-Ferrero, J., Garcia-Sanchez, I. M., \& CuadradoBallesteros, B. (2015). Effect of financial reporting quality on sustainability information disclosure. Corporate Social Responsibility Environmental Management, 22, 45-64.

Marques, P., Presas, P., \& Simon, A. (2014). The Heterogeneity of Family Firms in CSR Engagement: The Role of Values. SAGE Journal, 27 (3), 206-227.

Mason, C., \& Simmons, J. (2013). Embedding Corporate Social Responsibility in Corporate Governance: A Stakeholder Systems Approach. Journal of Business Ethics. Advance online publication: 10.1007/s10551-012-1615-9.

Miller, D., \& Le Breton-Miller, I. (2003). Challenge versus advantage in family business. Strategic Organization, 1 (1), 127-134.

Miller, D., Le Breton-Miller, I., Lester, R.H., \& Canella, A.A. (2007). Are family firms really superior performers? Journal of Corporate Finance, 13 (5), 829-858.

Moore, J.A., Shu, S.H., \& Werner, E.M. (2017). Dual entrenchment and tax management: Classified boards and family firms. Journal of Business Research, 79, 161-172.

Nekhili, M., Nagati, H., Chtioui, T., \& Rebolledo, C. (2017). Corporate social responsibility disclosure and market value: family versus non family firms. Journal of Business Research, 77 (C), 41-52.

La Porta, R. L., Lopez-de-Silane, F., Shleifer, A., \& Vishny, R. (1998). Agency problems and dividend policies around the world (No. w6594). National Bureau of Economic Research.

Landry, S., Deslandes, M., \& Fortin, A. (2013). Tax aggressiveness, corporate social responsibility, and ownership structure. Journal of Accounting, Ethics \& Public Policy, 14 (3), 611-645.

Leuz, R., Nanda, D., \& Wysocki, P. (2003). Earning Management and Investor Protection: An International Comparison. Journal of Finance and Economy, 69, 505-527.

Lin, K.Z., Cheng, S., \& Zhang, F. (2017). Corporate Social Responsibility, Institutional Environments, and Tax Avoidance: Evidence from a Subnational Comparison in China. International Journal of Accounting, 52, 303-318.

Lindblom, C. K. (2010). The implications of organizational legitimacy for corporate social performance and disclosure. Social and Environmental Accounting Volume Developing the Field, Sage: London, UK.

Orlitzky, M., Schmidt, F.L., \& Rines, S.L. (2003). Corporate social and financial performance: A meta-analysis. Organization Studies, 24 (3), 403-441.

Park, Y.W., \& Shin, H.H. (2004). Board Composition and Earnings Management in Canada. Journal of Corporate Finance, 10, 431-457.

Pazzaglia, F., Mengoli, S., \& Sapienza, E. (2013). Earnings quality in acquired and non acquired family firms: A socioemotional wealth perspective. Family Business Review, 26, 374-386.

Peasnell, K. V., Pope, P. F., \& Young, S. (2005). Board monitoring and earnings management: Do outside directors in- fluence abnormal accruals? Journal of Business Finance \& Accounting, 32 (7-8), 1311-1346.

Petersen, H., \& Vredenburg, H. (2009). Corporate governance, social responsibility and capital markets: exploring the institutional investor mental model, Corporate Governance, 9(5), 610-622.

Philips, R., Freeman, R. E., \& Wicks, A. C. (2003). What stakeholder theory is not. Business Ethics Quarterly, 13 (4), 479-502.

Prencipe, A., Markarian, G., \& Pozza, L. (2008). Earning management in family firms: Evidence from R\&D cat capitalization in Italy. Family Business Review, 21 (1), 71-88.

Press, E. G., \& Weintrop, J. B. (1990). Accounting-based constraints in public and private debt agreements. Journal of Accounting and Economics, 12(1-3), 65-95.

Prior, D., Surroca, J., \& Tribó, J. A. (2008). Are socially responsible managers really ethical? Exploring the relationship between earnings management and corporate social responsibility. Corporate Governance, 16(3), 160-177.

Riahi-Belkaoui, R. (2004). The impact of social responsibility on the informativeness of earnings and accounting choices. Advances in Environmental Accounting and Management, 2, 121-136.

Roychowdhury, S. (2006). Earnings management through real activities manipulation. Journal of Accounting and Economics, 42 (3), 335-370.

Sanchez-Ballesta, J.P., \& Garcia-Meca, E. (2007). A metaanalytic vision of the effect of ownership structure on firm performance. Corporate Governance, 15(5), 879-892.

Salewski, M., \& Zülch, H. (2014) (In press). The Association between Corporate Social Responsibility (CSR) and Earnings Quality-Evidence from European Blue Chips. HHL Working Paper No. 112. Available online: https://papers. ssrn.com/sol3/papers.cfm?abstract_id $=2141768$

Sharma, P. (2004). An overview of the field of family business studies: current status and directions for the future. Family Business Review, 17 (1), 1-36.

Shen, C. H., \& Chih, H. L. (2005). Investor protection, prospect theory, and earnings management: An international comparison of the banking industry. Journal of Banking and Finance, 29 (10), 2675-2697.

Shleifer, A. (2004). Does competition destroy ethical behaviour? American Economic Review, 94, 414-418.

Stockmans, A., Lybaert, N., \& Voordeckers, W. (2010). Socioemotional wealth and earning management in private family firms. Family Business Review, 23, 280-294.

Suchman, M. C. (1995). Managing legitimacy: Strategic and institutional approaches. Academic Managing Review, 20, 571-610.

Sun, N., Salama, A., Hussainey, K., \& Habbash, M. (2010). Corporate environmental disclosure, corporate governance and earnings management. Managerial Auditing Journal, 25(7), 679-700.

Surroca, J., \& Tribó, J. A. (2008) Managerial entrenchment and Corporate Social Performance. Journal of Business Finance and Accounting, 35 (5-6), 748-789.

Sweeney, A. P. (1994). Debt-covenant violations and managers' accounting responses. Journal of Accounting and Economics, 17(3), 281-308.

Teoh, S. H., Welch, I., \& Wong, T. J. (1998). Earnings management and the underperformance of seasoned equity offerings. Journal of Financial Economics, 50(1), 63-99.

Wang, D. (2006). Funding family ownership and earnings quality. Journal of Accounting Research, 44 (3), 619-656.

Warfield, T. D., Wild, J. J., \& Wild, K. L. (1995). Managerial ownership, accounting choices, and informativeness 
of earnings. Journal of Accounting and Economics, 20(1), 61-91.

Wiseman, R.M., \& Gómez-Mejía, L. R. (1998). A behavioral Agency Model of Managerial Risk Taking. The Academy of Management Review, 23(1), 133-153.

World Business Council for Sustainable Development. (2000). Meeting changing expectations.

Young, S., \& Marais, M. (2011). CSR reporting: An Institutional perspective. Finance and Corporate Governance Conference, La Trobe University.

Zang, A. (2012). Evidence on the tradeoff between real manipulation and accrual manipulation. Accounting Review, 87 (2), 675-703.

Zhong, K., Gribbin, D., \& Zheng, X. (2007). The effect of monitoring by outside block holders on earnings management. Quarterly Journal of Business and Economics, 46, 3760. 